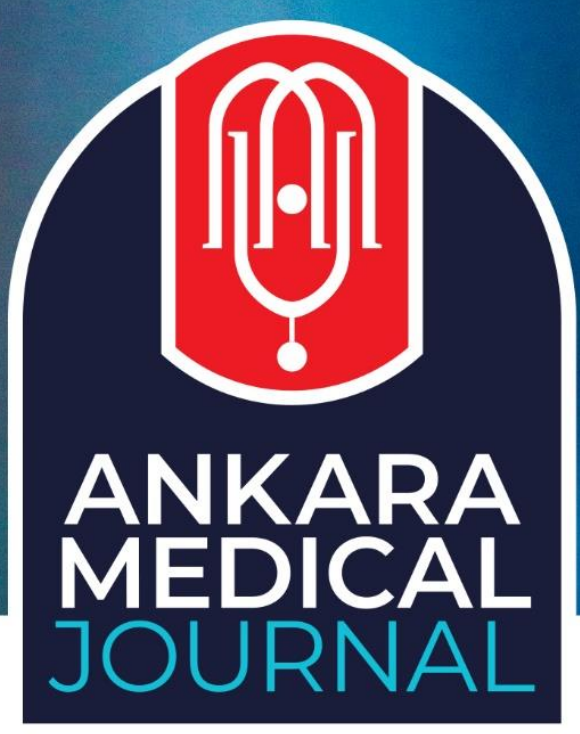

Research Article

Ankara Med J, 2020;(2):370-379 // (i) 10.5505/amj.2020.05826

\title{
COVID-19 PANDEMIC PROCESS: ITS EVALUATION IN TERMS OF SPREADING RATE, MORTALITY RATE AND PRECAUTIONS TAKEN
}

\section{COVID-19 PANDEMİ SÜRECİ: YAYILMA HIZI, ÖLÜM ORANI VE ALINAN ÖNLEMLER AÇISINDAN DEĞERLENDİRILIMESİ}

(D) Cüneyt Ardıç1, (D) Kerem Uzun1, (D) Ayşe Yazan Arslan1, (D) Ayse Sahin1, (i) Melek Hür1 ${ }^{1}$, (D) Merve Nur Serçe ${ }^{1}$, (i) Selma Türker ${ }^{1}$, (D) Büşra Usluoğlu' ${ }^{1}$, (D) Mert Süzük ${ }^{2}$, (i) Didem Sarimehmet ${ }^{3}$

${ }^{1}$ Recep Tayyip Erdoğan University Faculty of Medicine Department of Family Medicine, Rize, Turkey ${ }^{2}$ Adnan Menderes University Faculty of Medicine Department of Family Medicine, Aydın, Turkey ${ }^{3}$ Karadeniz Technical University Vocational School of Health Sciences, Department of Medical Services and Techniques, Trabzon, Turkey

Yazışma Adresi / Correspondence:

Cüneyt Ardıç (e-mail: drcuneytardic@hotmail.com)

Geliş Tarihi (Submitted): 05.05.2020// Kabul Tarihi (Accepted): 20.05.2020

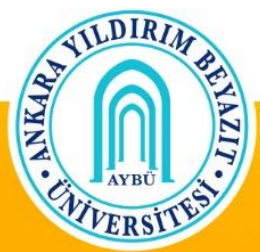

Ankara Yıldirım Beyazit University Faculty of Medicine Department of Family Medicine 


\title{
Öz
}

Amaç: 31 Aralık 2019'da Dünya Sağlık Örgütü (DSÖ) Çin Ülke Ofisi, Çin'in Hubei eyaletinin Vuhan şehrinde etiyolojisi bilinmeyen pnömoni vakalarını bildirmiștir. 7 Ocak 2020'de etken daha önce insanlarda tespit edilmemiş yeni bir Coronavirus (2019-nCoV) olarak tanımlanmıștır. Neredeyse tüm dünyaya yayılan bu durum sonrası Dünya Sağlık Örgütü tarafından bu salgın pandemi olarak ilan edilmiştir. Bu çalışmanın amacı pandemiyi 8 farklı ülkede analiz etmektir.

Materyal ve Metot: Çalışmaya 04.05.2020 tarihi itibari ile dünyada en fazla vakanın görüldüğü ülkeler (A.B.D, Çin, İtalya, Almanya, İran, Fransa, Türkiye) ve Güney Kore'yi dahil ettik. Ülkelerin toplam vaka ve ölüm sayılarını, ölüm oranlarını, 65 yaş üstü nüfus oranlarını ve alınan tedbirlerin tarihlerini birbirleriyle kıyaslayarak analiz ettik.

Bulgular: Tüm dünyadaki COVID’li vaka sayısı 3,6 milyonu aşmıștı ve bu vakaların yaklaşı $75,2 \%$ si 7 ülkede (A.B.D, İtaya, Çin, Almanya, Fransa, İran, Türkiye) görülmekteydi ve yine aynı tarihte (04.05.2020) dünyadaki ölüm sayısı 250 bini așmıștı.

Sonuç: Sağlık alanından ekonomiye kadar toplumu tüm yönleriyle etkilemiş olan son yüzyılın belki de insanlık tarihinin en büyük pandemisiyle karşı karşıyayız. İnsanlık tarihi için pandemiyle mücadeledeki en büyük silah ülkelerin bilgi birikimlerini birbirlerine aktarmaları olacaktır.

Anahtar Kelimeler: COVID-19, mortalite oranları, ülkelerin tedbirleri.

\begin{abstract}
Objectives: On 31 December 2019, the China Country Office of the World Health Organization (WHO) reported on cases of pneumonia with unknown etiology in the Wuhan city of the province of Hubei. On 7 January 2020, the factor was defined as a new Coronavirus (2019-nCoV) that had not been detected in humans before. The aim of this study is to analyze the pandemic in 8 different countries.

Materials and Methods: In the study, we included the countries with the highest numbers of cases by the date 04.05.2020 (USA, China, Italy, Germany, Iran, France, Turkey), as well as South Korea. We comparatively analyzed the countries' total case and mortality numbers, mortality rates, over- 65 years old population rates and dates of precautions that were taken.

Results: The number of COVID cases in the entire world exceeded 3.6 million, and approximately $75.2 \%$ of these cases were seen in 7 countries (USA, Italy, China, Germany, France, Iran, Turkey), whereas the number of related deaths worldwide exceeded 250 thousand by the same date (04.05.2020).

Conclusion: We are facing the greatest pandemic of the last century, or even the history of humanity, which has affected the society in all aspects from the field of medicine to economics. The greatest weapon for the history of humanity in the fight against the pandemic would be countries' transfer of their knowledge to each other.

Keywords: COVID-19, mortality rate, countries' precautions.
\end{abstract}




\section{Introduction}

Coronaviruses ( $\mathrm{CoV}$ ) are a large family of viruses that may lead to various diseases from the common cold to more serious diseases such as Middle East Respiratory Syndrome (MERS-CoV) and Severe Acute Respiratory Syndrome (SARS-CoV). ${ }^{1}$ On 31 December 2019, the China Country Office of the World Health Organization (WHO) reported on cases of pneumonia with unknown etiology in the Wuhan city of the province of Hubei. On 7 January 2020, the factor was defined as a new Coronavirus (2019-nCoV) that had not been detected in humans before. ${ }^{2}$ The epidemic spread to the entire world from China, and by April, it led to infections of more than 3.6 million people and the deaths of more than 250 thousand. ${ }^{3}$ All countries of the world are in an alarmed position for this pandemic where the largest effects of the world's near history are being seen from the social sphere to the economic sphere. According to the COVID-19 report of WHO for the People's Republic of China, the cases of mortality took place usually in people at advanced ages or individuals with a comorbid systemic disease (primarily hypertension, diabetes, cardiovascular disease, cancer and chronic pulmonary diseases, as well as other immunosuppressive conditions). ${ }^{4}$

The first imported case was a 61-year-old Chinese woman reported on 13 January 2020 from Thailand. ${ }^{5}$ While the number of countries reporting imported cases increased day by day, countries with domestic contagion started to appear in the late February. As the speed of the epidemic got lower in China at the beginning of March 2020, the COVID-19 cases and related mortalities were increasing in Iran, Republic of Korea (South Korea), USA, France and Italy. ${ }^{6}$ After this rapid spread, this epidemic was announced as a pandemic by the World Health Organization.

The different courses of numbers of cases in every country, and likewise, different mortality rates in every country have provided space for revelation of these differences. ${ }^{7}$

The purpose of our study is to reveal the population distributions of 8 different countries where the COVID-19 pandemic has seen (USA, France, Italy, China, Iran, Germany, Turkey, South Korea), the numbers of the first 1015-20-30 days and the latest current cases and mortalities, the precautions taken in the country after encountering the first case and dates of precautions, as well as offering risk mitigation strategies for these countries for further dates.

\section{Materials and Methods}

In the study, we included the countries with the highest numbers of cases by the date 01.05.2020 (USA, China, Italy, Germany, Iran, France. Turkey), as well as South Korea. By recording the numbers of cases and mortalities 


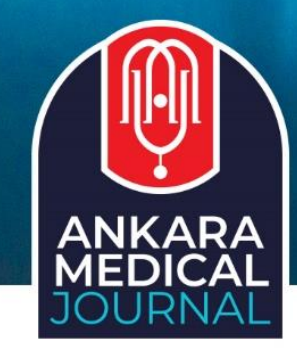

in the countries starting with the dates where the first case and mortality were observed on a daily basis, we obtained the countries' case and mortality plots (Figure 1-2).

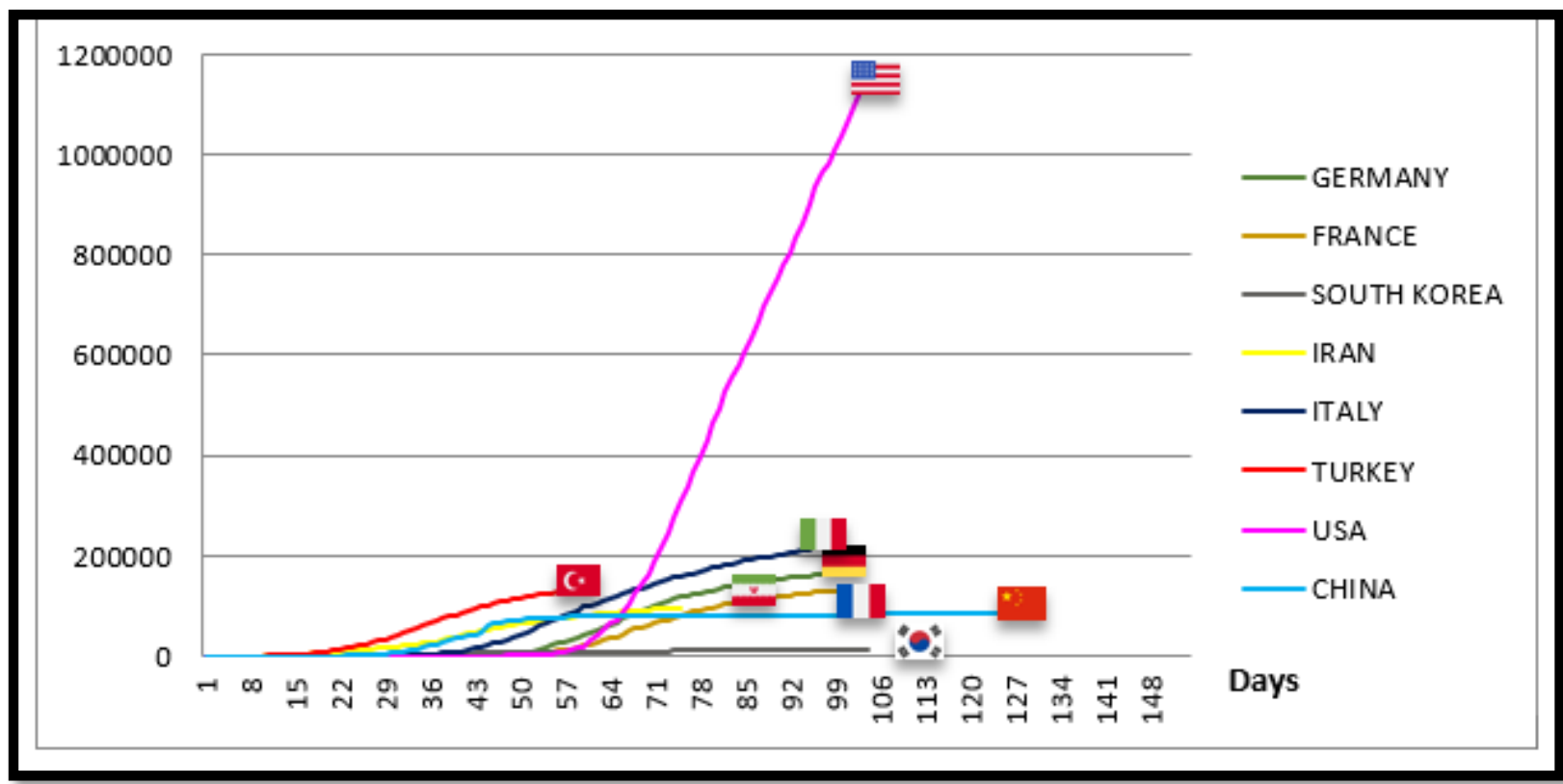

Figure 1. Cumulative numbers of COVID-19 cases in selected countries

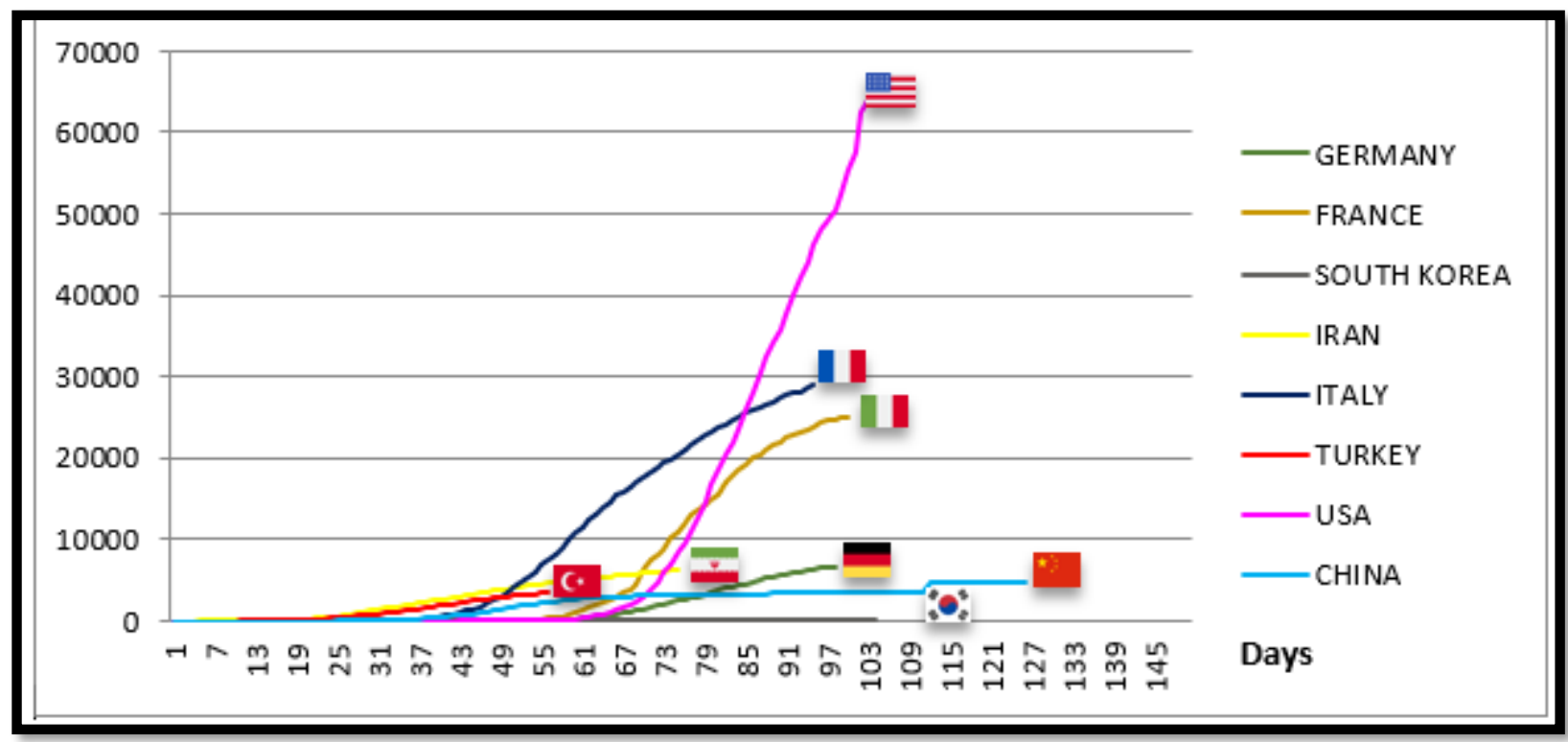

Figure 2. Numbers of COVID-19 death cases in select countries 


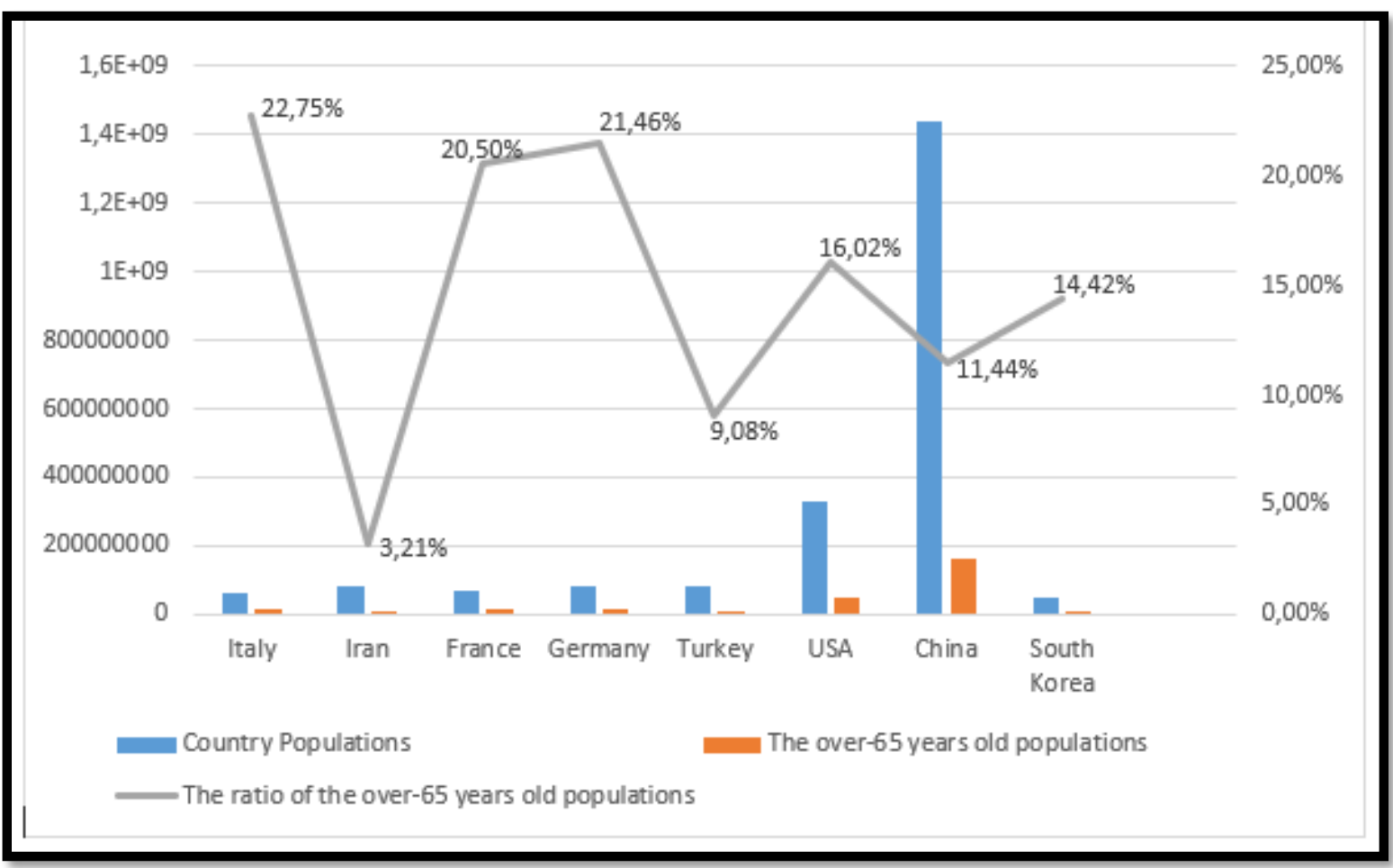

Figure 3. Distrubition of population over 65 years of age in countries

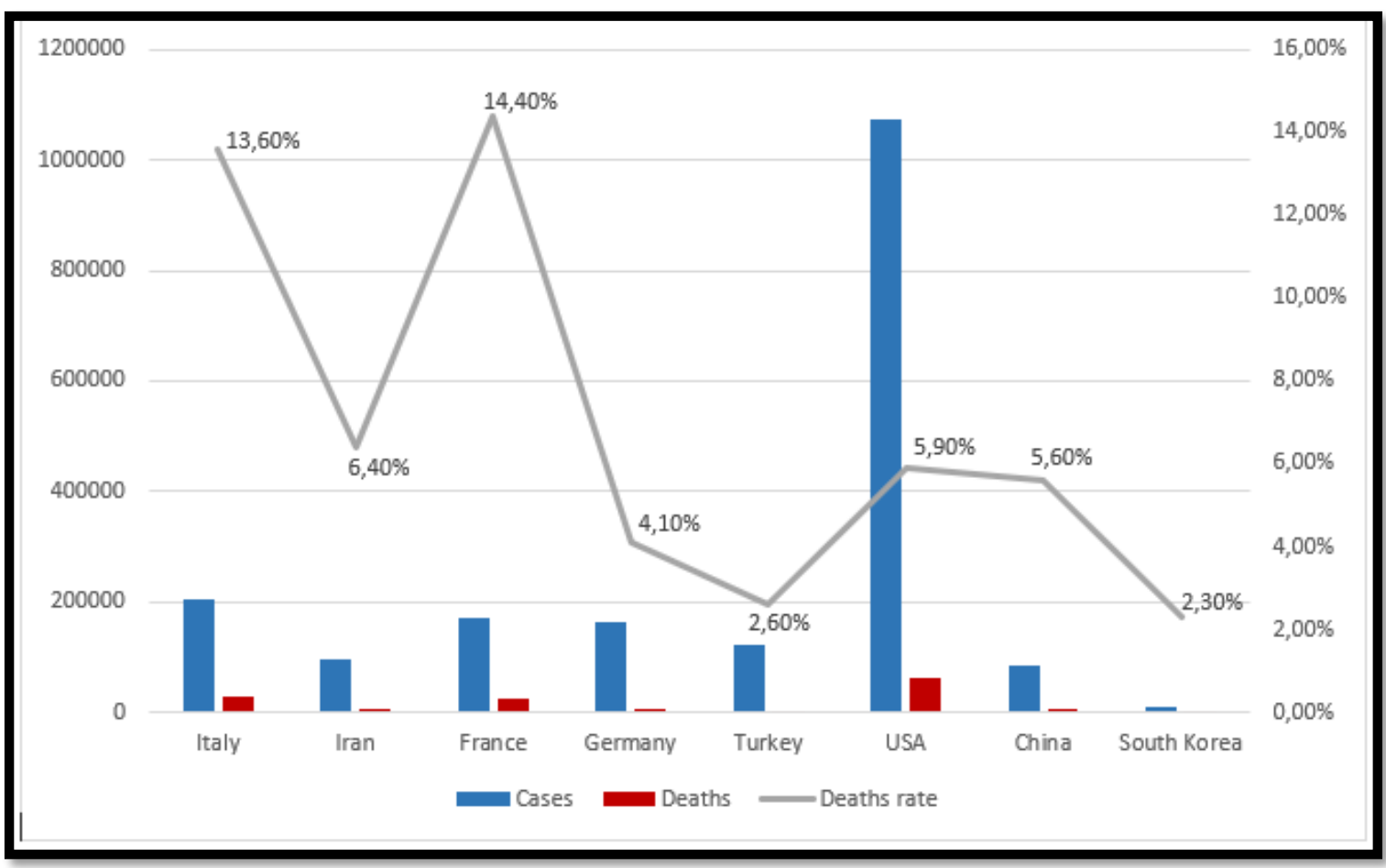

Figure 4. Novel Coronavirus (2019-nCoV) cases, deaths and deaths rate by countries 


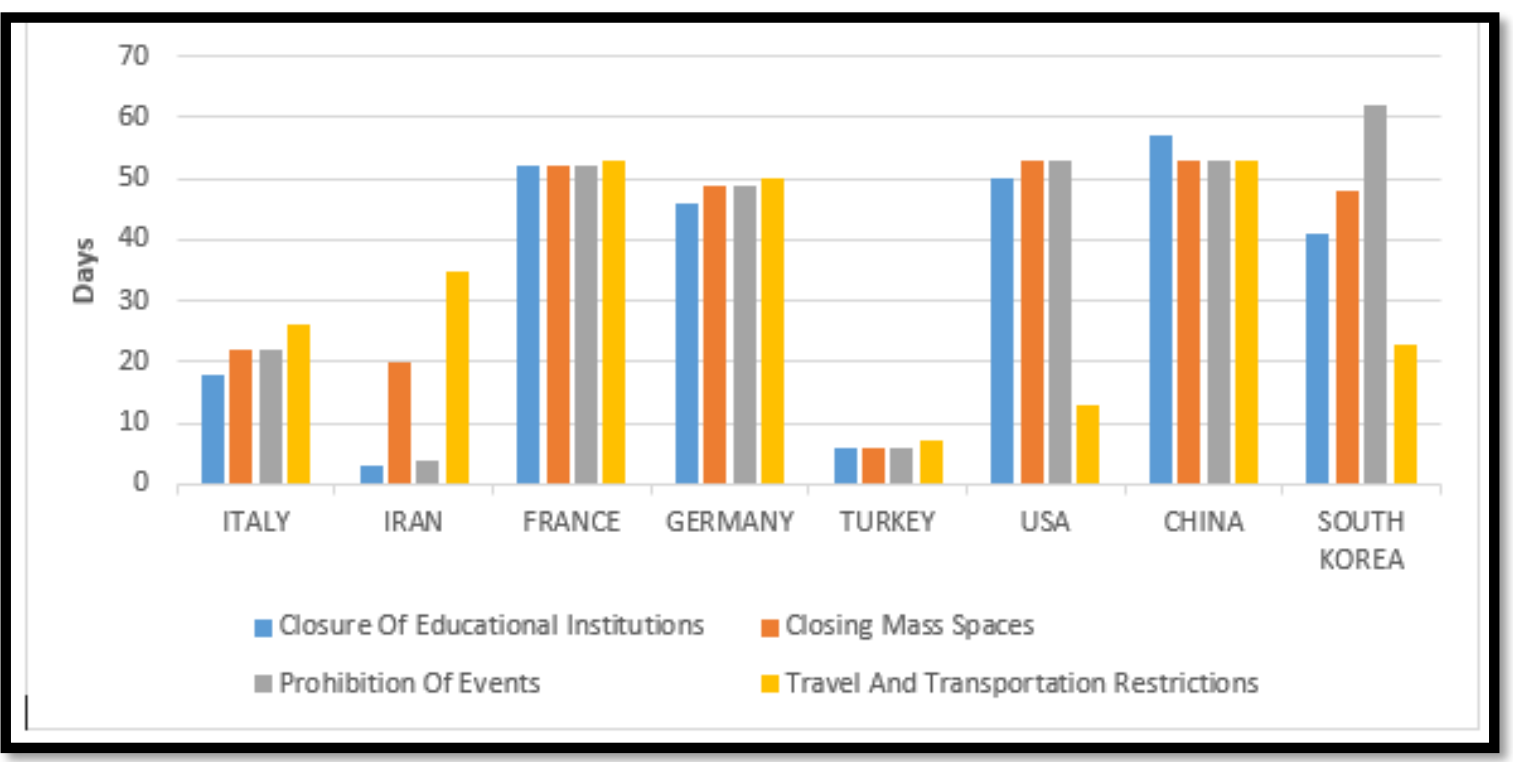

Figure 5. Time interval to take precautions after the first case in each country

By obtaining the official populations and the over-65 years old populations of the countries, we calculated the ratio of the over-65 years old population to the entire population (Figure 3). We also found the mortality rates of the countries by proportioning the number of deaths in the countries to the number of cases there (Figure 4).

Figure 5 shows the precautions that were taken after the first case observed in the country (closing schools, prohibitions and precautions for flights, closure of public spaces (museum, library, cinema, mosque, etc.), cancellation of meetings and activities, quarantine for those coming from abroad, curfew), as well as the dates of the precautions and cases of mortality.

\section{Results}

By the moment we were writing this article (04.05.2020), the number of COVID cases in the entire world had exceeded 3.6 million, and approximately $75.2 \%$ of these cases were seen in 6 countries (USA, Italy, China, Germany, France, Iran, Turkey), whereas the number of mortalities in the world by the same date (04.05.2020) had exceeded 250 thousand. The countries with the highest number of mortalities were the same as those above except for Germany, which was replaced by the United Kingdom in this ranking.

Another interesting finding was the over- 65 population ratios of the countries. Among the 8 countries that we analyzed, Italy, which also had the second most deaths, was in the first place by $22.75 \%$. Italy, which had the highest elderly population ratio, also had the highest mortality rate $(13.60 \%)$. 
Germany, which was in the second place in terms of the over-65 population ratio after Italy by $21.46 \%$, was in the sixth place among the 8 countries in terms of mortality rates (4.10\%), as opposed to the case in Italy. Turkey was in the 7 th place based on the mortality rates by $2.60 \%$.

\section{Discussion}

\section{South Korea}

South Korea was among the countries with the most successful management of COVID-19 among the analyzed 8 countries by the date of 04.05.2020. When the causes of this success were examined, the number of tests that were conducted was noteworthy. The country had done more than 500 thousand tests. ${ }^{8}$ COVID-19 spreads very rapidly from human to human, ${ }^{9}$ and because of this, in addition to isolation of people, social distancing and quarantine policies, faster detection of infected cases should reduce the growth of the cases. Each infected individual may be contagious for a set of people by contacting others directly or indirectly (i.e. by activity). For this reason, to reduce the probability of the virus to be transmitted, faster detection of infected individuals may play an important role in addition to lock-down strategies. The first cases in the country were reported at the end of January. As the number of cases grew, officials started a huge contact monitoring and testing regimen to define and isolate infected individuals, and they even directly established test centers. Considering the number of tests in every country per 1 million individuals, South Korea is at the top with 3 thousand 692. This shows that, in South Korea, 3 thousand 692 of every 1 million people has taken the test. ${ }^{8}$ The magnitude of this number explicitly shows South Korean policy of reducing detection times with a faster detection strategy. ${ }^{10}$ Additionally, considering the precautions that were taken, we may state that South Korea was mobilized after the first case seen in Wuhan. Local governments in Korea conduct epidemiological research and take quarantine precautions after informing Korean Centers of Disease Control and Prevention (KCDC). After this, local governments firstly applied basic epidemiological research and quarantine precautions, and then, they reported their activities step by step.

\section{Italy}

Italy, where the first case was reported on 21 February 2020, unfortunately became the country with the most dramatic course of COVID-19 by 04.05 .2020 with more than 200 thousand cases and more than 29 thousand deaths. Considering the reasons for this poor outcome, it is noteworthy that Italy has the highest proportion of the elderly among the examined 8 countries. However, the fact that its condition is much worse in comparison to Germany which has almost the same proportion of the elderly cannot be explained solely by the elderly population ratio. If we look at the precautions taken by the Italian government since the date of 21 February where the first case was seen, we may state that Italy was late in comparison to other countries. For example, 
school were closed on 4 March 2020, 17 days after the first case, ${ }^{11}$ whereas prohibition and restriction of flights were declared on 12 March 2020.12 The fast increase in the numbers of cases and deaths finally forced the government to issue a curfew on 20 March 2020.13 Another reason that increased the mortality rate was that, while the number of intensive care beds per 100 thousand people is 29.2 in Germany with almost the same ratio of elderly people, this number is 12.5 in Italy.

\section{Germany}

The much lower number of mortalities so far in comparison to other countries attracted the attention of the whole world towards the strategy followed by Germany and their precautions. The Merkel government is applying the recommendations of the Robert Koch Institute with a history of 129 in fighting with the coronavirus pandemic. Germany is following three main strategies for this fight. COVID-19 cases are diagnosed fast with tests and then isolated, and those who are in contact with these people are also determined and isolated. Additional protection measures are taken for those at advanced ages or chronic diseases and vulnerable groups in need of protection. The healthcare system is being strengthened. Regarding COVID-19, in addition to test capacities, the intensive care and ventilator capacities at hospitals are also being increased. The government, which has implemented precautions one by one after collaborations with institutions consisting of several fields from education to sports and telecommunication and civil society organizations, has also passed an economy package of 750 billion euros from the German Federal Parliament. The days ahead will show whether or not the success achieved so far will last, whether or not the mortality rates will increase and with how much damage Germany will get out of this crisis as the largest economy of Europe.

\section{USA}

The USA, with about 63 thousand COVID-19-related mortalities by 04.05.2020, has left behind China, which was the origin of the epidemic and reported some 3 thousand 305 deaths. Likewise, by the same date, the number of cases in the USA exceeded 1 million and was determined to be higher than a third of all cases in the world. The fast increase in the number of cases was also related to the number of tests that were run. By 04.05.2020, more than 500 thousand tests were applied. ${ }^{14}$ We may state that the USA is under a serious threat by the COVID-19 pandemic with an over-65 elderly population of more than 52 million. ${ }^{15}$ The country where there are 34.7 intensive care beds for every 100 thousand people may be considered to be in a better condition than other countries in this matter. 13 days after the date of the first case, 20.01.2020, flight prohibitions started, ${ }^{16}$ while schools were closed on 13 March 2020. ${ }^{17}$ These days, where were cannot completely know about the extent to which the epidemic will reach, Doctors Deborah Birx and Anthony Fauci in the Task Force of the White House against COVID-19 stated that 100 to 240 thousand people could die due to the virus even in the case of abiding by the precautions taken in the USA against the pandemic. ${ }^{18}$ 


\section{China}

The process followed by China, which was the origin of the virus, is closely followed by other countries. Upon observing a fast increase in the number of cases in the first week of January, the Beijing government placed the Hubei province with a population of 55 under quarantine on 23 January 2020. On 12 February, the record-level number of cases was noted. More than 15 thousand new cases were observed per day. After this, a set of precautions were taken including closure of public areas, cancellation of meetings and activities and quarantine coverage for those coming from abroad. ${ }^{19}$ At the end of February, the daily number of cases decreased to approximately 500 . In mid-March, it was claimed that $85 \%$ of cases recovered. The fact that no new cases were reported by the end of March in the country with a mortality rate of approximately $4 \%$ led other countries, especially the USA, to look at the numbers reported by the Chinese government with suspicion.

\section{Turkey}

The country where the first case was detected later than those in other European countries (10.3.2020) gained an advantage in this matter by utilizing the experiences of other countries. The government of the Republic of Turkey, which acted faster, closed down all schools around the country on the date of 13.3.2020. The precautions were rapidly increased in the country, and by 16.3.2020, a set of new precaution were brought to include cancellation of meetings and activities, prohibition of mass prayers at mosques, restrictions on domestic and international flights, cancellation of sports events and closure of social spaces. The mortality rate in the country is around $2.60 \%$. Turkey, where there are 40 intensive care beds per every 100 thousand individuals, is at the top of the list in this matter. In the country with the over-65 elderly population ratio of $9.1 \%$, by the end of March, the number of cases was higher than 15 thousand, while the number of mortalities was 277.

\section{Iran}

Although Iran is the country with the lowest elderly population ratio among the countries we investigated (3.21\%), its high mortality rate is noteworthy (6.40\%). This situation may be explained by the insufficient precautions in the country and the inadequacy of the healthcare system. In Iran, where the number of cases was higher than 50 thousand, the number of intensive care beds for every 100 thousand people is only 4.6. This is the lowest rate among all 8 countries.

\section{France}

Although the elderly population ratio in the country (20.5\%) is similar to that in Germany, its mortality rate $(14.40 \%)$ was almost 3 times that of Germany. The reduction in the number of new cases by mid-March may 
be associated with the increased number of tests. By the end of March, the number of tests in the country had exceeded 100 thousand. ${ }^{20}$ The fact that the schools were only closed down 47 days after (16.3.2020) the date of 24.1.2020 when the first case was observed contributed to the increase in the number of cases. The number of deaths in the country was higher than 25 thousand, and France was the first among the countries with the highest numbers of mortality rate.

We are facing the greatest pandemic of the last century, or even the history of humanity, which has affected the society in all aspects from the field of medicine to economics. The greatest weapon for the history of humanity in the fight against the pandemic would be countries' transfer of their knowledge to each other. In this article where 8 different countries were analyzed, the differences in the numbers of cases and mortalities among the countries were investigated.

\section{References}

1. Su, S.,Wong, G., Shi, W., Liu, J., Lai, A. C., Zhou, J. et al. Epidemiology, genetic recombination, and pathogenesis of coronaviruses. Trends in microbiology, 2016;24(6):490-502.

2. Z.Wu and J. M. McGoogan. Characteristics of and Important Lessons From the Coronavirus Disease 2019 (COVID-19) Outbreak in China: Summary of a Report of 72314 Cases From the Chinese Center for Disease Control and Prevention. JAMA, 02 2020. (doi:10.1001/jama.2020.2648)

3. Royallab Stats (2020), Coronavirus Pandemic: Real Time Counter, World Map, News. [Internet]. https://www.youtube.com/watch?v=SLV1B5Lzy48\&feature=emb rel err (Access Date: 01.05.2020)

4. World Health Organization (2020), Coronavirus Disease (COVID-19) Pandemic. [Internet]. https://www.who.int/emergencies/diseases/novel-coronavirus-2019 (Access Date:30.04.2020)

5. World Health Organization (2020), Novel Coronavirus-Thailand (ex-China). [Internet]. https://www.who.int/csr/don/14-january-2020-novel-coronavirus-thailand-ex-china/en/ (Access Date:25.04.2020 )

6. Republic of Turkey Ministry of Health, Current Situation in Turkey. [Internet]. https://covid19.saglik.gov.tr/ (Access Date:01.05.2020)

7. Worldometers. COVID-19 Coronavirus Pandemic. [Internet]. https://www.worldometers.info/coronavirus/\#countries (Access Date:01.05.2020)

8. Centers for Disease Control and Prevention (2020). The Uptades of COVID-19 in Republic of Korea. [Internet]. https://www.cdc.go.kr/board/board.es?mid=\&bid=0030 (Access Date:25.04.2020)

9. Simiao Chen, Juntao Yang, Weizhong Yang, Chen Wang, and Till Bärnighausen. Covid-19 control in china during mass population movements at new year. The Lancet, 2020.

10. Worldometers (2020). COVID-19 Coronavirus Testing: Criteria and numbers by country, 2020. [Internet]. https://www.worldometers.info/coronavirus/covid-19-testing/ (Access Date:30.04.2020) 
11. Monica Guerzoni-Valentina Santarpia,Corriere della Sera (2020) COVID-19: Coronavirus, school closed throughout Italy until mid-March. Available:

https://www.corriere.it/scuola/20 marzo 04/coronavirus-scuole-chiuse-tutta-italia-decisionegoverno-entro-stasera-e7ba0614-5e12-11ea-8e26-25d9a5210d01.shtml (Access Date:30.04.2020)

12. Ministry of Infrastructure and Transport of Italy, Coronavirus: De Micheli signs decree on airtransport. [Internet].

http://www.mit.gov.it/comunicazione/news/coronavirus-de-micheli-firma-decreto-su-trasporto-aereo (Access Date:24.04.2020)

13. İl Post (2020). The new restrictions decided by the government. [Internet].

https://www.ilpost.it/2020/03/20/ordinanza-coronavirus-attivita-sportiva-correre/ (Access Date:30.04.2020)

14. Centers for Disease Control and Prevention (2020) Coronavirus Disease 2019 (COVID-19). Testing in the US. [Internet].

https://www.cdc.gov/coronavirus/2019-ncov/cases-updates/testing-in-us.html (Access Date:01.05.2020 )

15. data.census.gov [Internet] https://data.census.gov/cedsci/. (Access Date:01.05.2020)

16. Depatment of Homeland Security. U.S Customs and Border Protection, Transportation Security Administration: Notice of Arrival Restrictions Applicable to Flights Carrying Persons Who Have Recently Traveled from or were otherwise present within the People's Republic of China [Internet]. https://www.dhs.gov/sites/default/files/publications/20_0202 dhs-arrival-restriction-frn-2.pdf

17. Authenticated US Comment İnformation (2020). Federal Register/Vol. 85 No. 43 /Wednesday, March 4, 2020/Rules and Regulations 12731 [Internet].

https://www.dhs.gov/sites/default/files/publications/2020-04542.pdf

18. The New York Times (2020). Coronavirus Live news uptades. White House Projects Grim Toll From Coronavirus. [Internet].

https://www.nytimes.com/2020/03/31/world/coronavirus-live-news-updates.html (Access Date:30.04.2020)

19. Wikipedia (2020). 2019-20 Coronavirus pandemic in mainland China. [Internet]. https://en.wikipedia.org/wiki/2019\%E2\%80\%9320 coronavirus pandemic in mainland China\#Cance llations, delays and shutdowns (Access Date20.04.2020)

20. Sante publique France (2020). COVID-19. Epidemiological uptade of March 24, 2020. [Internet]. https://www.santepubliquefrance.fr/maladies-et-traumatismes/maladies-et-infectionsrespiratoires/infection-a-coronavirus/documents/bulletin-national/covid-19-point-epidemiologique-

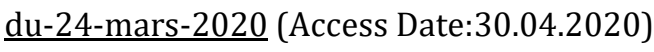

